\title{
Strategies For Creative Economic Development In Malang Raya
}

\author{
${ }^{\mathrm{a}}$ University of Widyagama, Faculty of Economics, Malang-Indonesia \\ ${ }^{\mathrm{b}}$ University of Widyagama, Faculty of Economics, Malang-Indonesia \\ ${ }^{c}$ University of Widyagama, Faculty of Economics, Malang-Indonesia
}

Tuti Hastuti ${ }^{\mathrm{a}}$, Marjani Ahmad Tahir ${ }^{\mathrm{b}}$, Endah Puspitosarie

Correspondence Author: Tuti Hastuti, Faculty of Economic, University of Widya Gama Malang, Jl. Borobudur No.35, Blimbing, Malang City, East Java, 65141, Indonesia

E-mail:- tutihastutiuwg2@gmail.co

Received date: 15 August 2019, Accepted date: 30 September 2019, Online date: 28 October 2019

Copyright: (C) 2019 Tuti Hastuti et al, This is an open-access article distributed under the terms of the Creative Commons Attribution License, which permits unrestricted use, distribution, and reproduction in any medium, provided the original author and source are credited.

\begin{abstract}
This research has several objectives, which include: (1) understanding creative economic potentials in Malang Raya; (2) analyzing creative economic development; and (3) conceptualizing comprehensive ideas of creative economic that comprise various activities from finding creative economic in a region to making strategic plan for developing it. Three analysis methods used by this research, respectively, are: (1) Location Quotient (LQ) Analysis; (2) Shift Share (SS) Analysis; and (3) SWOT Matrix Analysis. Some findings were obtained, and the explanation is given as follows. Leading sectors in Malang City include: (a) Sector of Water Supply, Trash \& Waste Management, and Recycle; (b) Sector of Construction; (c) Sector of Wholesale \& Retail Tradings and Reparation of Cars \& Motorcycles; (d) Sector of Finance and Insurance Services; (e) Sector of Education Services; and (f) Sector of Health and Social Activity Services. Leading sectors in Batu City consist of: (a) Sector of Agriculture, Forestry and Fishery; (b) Sector of Construction; (c) Sector of Wholesale \& Retail Tradings and Reparation of Cars \& Motorcycles; (d) Sector of Accommodation and Food \& Beverage Provisioning; and (e) Sector of Other Services. Leading sectors in Malang Regency comprise: (a) Sector of Agriculture, Forestry and Fishery; (b) Sector of Processing Industry; and (c) Sector of Other Services. Result of SWOT analysis showed that strategic position of creative economic in Malang Raya is described as that growing and developing. The suggested alternative of strategy to be used in the future is market development strategy.
\end{abstract}

Keywords: Creative Economic, Competing Ability, Industry 4.0

\section{INTRODUCTION}

Industry 4.0 has given new hopes not only for the acceleration of economic progress but also the wide opening of employment in Indonesia. Digital interconnection is successful in shortening trade chain of products, which as a result, then increases mobility speed of goods and services from producers to consumers. If this may persist, then it can reduce operational cost, improve economic activity, and increase producer income and consumer efficiency. Industry 4.0 presumably threats labor welfare because it may inflict downsize, but not all industries suffer from this threat. Among the industries less vulnerable to labor downsize is creative industry because this industry is mostly relying on creativity, art, culture, and innovation. Furthermore, a study by Nesta (2015), which is titled as "Robot versus Creativity" and ever quoted in Media Indonesia (2019), had mentioned that jobs at creative sector are successful to hold out despite automatization threat. In US, $86 \%$ creative jobs are successfully persisting whereas, in UK, it is $87 \%$. As said by Nesta, creative sector, if it is seriously fostered, can be economic driving key factor in twenty-first century.

The creative industry has developed significantly in many countries. England creative industry demonstrates a significant development with average growth of 9\% per year. Gross Domestic Income (GDI) of Indonesian creative economy is growing significantly and outnumbering the total of National Gross Domestic Income, precisely by $8.5 \%$ in 2016, $9.5 \%$ in $2017,10.5 \%$ in 2018, and estimated $12 \%$ in 2019.

Malang Raya is populated with 3.5 millions heads and has become a potential market for creative industry. Of total proportion of Gross Regional Domestic Income (GRDI), more than 60\% derive from sectors that consume creative industry (koran-sindo.com). The creative industry in Malang Raya has been supportive of national economic growth and people welfare. 
Citation: Tuti Hastuti, et al., Strategies For Creative Economic Development In Malang Raya. Australian Journal of Basic and Applied Sciences, 13(10): 73-82. DOI: $10.22587 / a j b a s .2019 .13 .10 .10$

The question is how creative industry maintains its role, and this is supposed to be an interesting topic for discussion in many forums.

After mapping various supply chain networks, Yudha Prasetyawan et al. (2013) concluded that stakeholders are the main supporting factor to the business. The creative industry in Malang Raya is considered financially healthy because it produces positive Net Present Value (NPV) for IDR 42,316,170.61 and Internal Rate of Return (IRR) for 19.79\%.

A study by Dias \& Ayu (2011) generated a finding that clothing distribution outlet (distro) industry in Malang City is lacking support from Malang City Government and other related institutions. Meanwhile, Netty (2014) discovered that although pro-poor tourism is not yet conceptualized as a development strategy, creative economic at tourism sector in Batu City has brought significant change on Batu people. Moreover, Ruth (2014) found that culinary cluster in Malang City is an excellent potential to be developed as a creative economic development model.

All studies referenced above are still partial because not only it is not yet describing actual conditions of creative economic in Malang Raya but also not yet elaborating the development base for the creative industry. Therefore, it is essential to conduct deep and comprehensive review onto creative industry entrepreneurs in Malang Raya to improve their competing ability and also to increase local economic growth in many regions of Malang Raya.

\section{REVIEW OF LITERATURES}

\section{Definition of Creative Economy}

Creative Economy is a concept of economy in the age of new economy which intensifies information and creativity by relying on ideas and stock of knowledge derived from Human Resource (HR) as the key production factor in economic activity. Worldwide economic structure has been subjected to a rapid transformation with the increase of economic growth. Economic structure has also shifted from Natural Resource (NR)-based to Human Resource (HR)-based. The age of the world is also shifting from the age of agriculture to the age of industry and information.

Howkins (2001) in the book entitled "The Creative Economy" was admitting the significance of creative economy wave after realizing a fact for the first time in 1996 that the export of United States copyrights has given a big sale for US\$ 60.18 billions outnumbering the combined total export of other sectors involving automotive, agriculture and aeroplane.

"Creative Economy" is a term starting to be known globally after the release of the book entitled "The Creative Economy: How People Make Money from Ideas" (2001) written by John Howkins. He recognized the new economic wave based on creativity as a very promising progress after he witnessed in 1997 that the United States has earned 414 billions dollars from selling the products of Intellectual Property Right to abroad, and it makes this Right as the number-one export in United States.

\section{The Scope of Creative Economy}

The scope of creative economy is represented by 16 sectors (industries), namely: architecture; interior design; visual communication design; product design; fashion; film, animation and video; photography; handicraft; culinary; music; application and game developer; publishing; advertising; performance art and fine art; and television \& radio (President Decree No.72/2015). The arm length of the government for administering creative industries is Creative Economy Agency. This agency provides facilities needed by the sectors, such as supportive programs, human resource with good quality, and other structuresinfrastructures related to creativity.

\section{Previous Researches}

Yudha Prasetyawan et.al. (2013) conducted research in Malang Regency context entitled with "The Identification of the Lamp-Hood Making as Core Competence and Leading Product of the Creative Industry in Malang Regency". This research used approaches such as value chain and supply chain management and determined the needed strategy based on CIMOSA business model. This research gave some results. Based on supply chain network map, the stakeholders are supporting the business of Small-Medium Enterprises (SME). Competitive advantage can be increased by improving the collaboration and coordination system, designing the effective and efficient supply chain network, and applying CIMOSA business model to SME. After analyzing value chain, supply chain network, and business model, then financial analysis is implemented. The creative industry in Malang Regency is considered as financially reliable because it has positive NPV in IDR 42,316,170.61 with IRR of $19.79 \%$. The IRR exceeds the predetermined discount rate of $14 \%$. The Government of Malang Regency shall maximize the business of the creative industry to improve local economy and also to take preparation for welcoming AEC 2015.

Dias \& Ayu (2011) carried out research in the context of Malang City with the title "Problems in the Creative Industry of Clothing Discount Stores in Malang City". Their research used qualitative data analysis involving SWOT analysis on external and internal factors. They found that clothing discount stores in Malang City are not given adequate supports and attentions by the Government of Malang City and other relevant agencies. The development of the creative industry of clothing discount stores is not yet optimum for improving the economy of Malang City. Clothing discount stores and other creative industries shall have important contribution to the increase of creative value produced by creative workers and also help increasing competitive advantage of these workers compared to other workers in Malang City.

Netty (2014) did research with Batu City context with the title "The Analysis on Creative Economy Contribution from Tourism Sector to the Improvement of Community Welfare in Batu City". The qualitative approach to primary data was used in this research. Data were collected by interview and observation with the enterprises in tourism sector. The result showed that the development of tourism sector in Batu City had brought a great change to community, but it was not maximally used because 
Citation: Tuti Hastuti, et al., Strategies For Creative Economic Development In Malang Raya. Australian Journal of Basic and Applied Sciences, 13(10): 73-82. DOI: $10.22587 /$ ajbas.2019.13.10.10

many community members still did not realize the importance of exploiting the existing tourism potentials. There are no specific strategies which are pro-for-tourism, but central government has set policies relevant to the concept of pro-for-tourism.

Ruth (2014) performed research in Malang City and it was entitled with "Strategies for Developing Creative Economy-Based Culinary Business in Malang City". This research used descriptive qualitative method with case study. It found that culinary cluster in Malang City has huge potentials to be developed with creative economy development model.

\section{METHOD OF RESEARCH}

Research type was descriptive but using both quantitative and qualitative approaches. Scope of research was emphasized on identification of policies and variables related to creative economic potentials in Malang Raya (Malang City, Malang Regency, and Batu City). Identification was done by observing economic, social and cultural potentials at surrounding communities. Data type in this research was primary and secondary data. Data collection was done with observation, interview and questionnaire.

Analysis method in this research comprised Location Quotient (LQ) Analysis, Shift Share (SS) Analysis, and SWOT Matrix Analysis. The research was operated with survey that is applied to creative economic entrepreneurs in each selected region. Quantitative and qualitative data about creative economic were collected from the Office of Industry, Trade and Cooperatives at each studied region. Primary data were obtained from questionnaire distributed to creative economic entrepreneurs.

V.

\section{RESULT OF RESEARCH}

\section{Analysis of Competing Ability}

The economic development pattern of Malang City resides at Quadrant I. Compared to other regions in East Java, in average, Malang City has not only faster economic progress but also higher economic growth rate and higher income per capita.

Table 1: Klassen Typology for Malang City from 2015 to 2018

\begin{tabular}{|c|c|c|c|c|c|c|c|}
\hline \multirow[t]{2}{*}{ Year } & \multicolumn{3}{|c|}{ Economic Growth Rate (R) } & \multicolumn{3}{|c|}{ GRDI per Capita (Y) } & \multirow[t]{2}{*}{ Conclusion } \\
\hline & Malang City (Rij) & East Java Province $(\mathbf{R j})$ & Remark & Malang City (Yij) & East Java Province (Yj) & Remark & \\
\hline 2015 & $5.61 \%$ & $5.35 \%$ & $\mathrm{Rij}>\mathrm{Rj}$ & $60,876,912$ & $43,578,103$ & $\mathrm{Yij}>\mathrm{Yj}$ & Quadrant I \\
\hline 2016 & $5.61 \%$ & $5.80 \%$ & $\mathrm{Rij}<\mathrm{Rj}$ & $66,757,279$ & $47,473,717$ & $Y i j>Y j$ & Quadrant II \\
\hline 2017 & $5.69 \%$ & $5.08 \%$ & $\mathrm{Rij}>\mathrm{Rj}$ & $72,391,793$ & $51,388,318$ & $Y i j>Y j$ & Quadrant I \\
\hline 2018 & $5.71 \%$ & $4.94 \%$ & $\mathrm{Rij}>\mathrm{Rj}$ & $77,365,187$ & $55,436,368$ & $Y i j>Y j$ & Quadrant I \\
\hline
\end{tabular}

Source: Data were processed

Malang Regency is in Quadrant III. This is a developing region with high economic growth rate. However, in average, its income per capita is still lower than in other regions in East Java.

Table 2: Klassen Typology for Malang Regency from 2015 to 2018

\begin{tabular}{|c|c|c|c|c|c|c|c|}
\hline \multirow[t]{2}{*}{ Year } & \multicolumn{3}{|c|}{ Economic Growth Rate (R) } & \multicolumn{3}{|c|}{ GRDI per Capita (Y) } & \multirow[t]{2}{*}{ Conclusion } \\
\hline & $\begin{array}{l}\text { Malang Regency } \\
\text { (Rij) }\end{array}$ & $\begin{array}{c}\text { East Java Province } \\
(\mathbf{R} \mathbf{j})\end{array}$ & Remark & $\begin{array}{c}\text { Malang Regency } \\
\text { (Yij) }\end{array}$ & $\begin{array}{c}\text { East Java Province } \\
(\mathbf{Y} \mathbf{j})\end{array}$ & Remark & \\
\hline 2015 & $5.27 \%$ & $5.35 \%$ & $R i j<\mathrm{Rj}$ & $29,022,322$ & $43,578,103$ & $\mathrm{Yij}<\mathrm{Yj}$ & $\begin{array}{l}\text { Quadrant } \\
\text { VI }\end{array}$ \\
\hline 2016 & $5.30 \%$ & $5.80 \%$ & $R i j<R j$ & $31,943,823$ & $47,473,717$ & $Y i j<Y j$ & $\begin{array}{c}\text { Quadrant } \\
\text { VI }\end{array}$ \\
\hline 2017 & $5.43 \%$ & $5.08 \%$ & $R i j>R j$ & $34,611,631$ & $51,388,318$ & $Y i j<Y j$ & Quadrant III \\
\hline 2018 & $5.57 \%$ & $4.94 \%$ & $R i j>R j$ & $37,025,651$ & $55,436,368$ & $\mathrm{Yij}<\mathrm{Yj}$ & Quadrant III \\
\hline
\end{tabular}

Source: Data were processed

Batu City has its economic development pattern situated on Quadrant I. If compared to other cities in East Java Province, in average, Batu City has faster progress, and indicates higher economic growth rate and also greater income per capita.

Table 3: Klassen Typology for Batu City from 2015 to 2018

\begin{tabular}{|c|c|c|c|c|c|c|c|}
\hline \multirow[t]{2}{*}{ Year } & \multicolumn{3}{|c|}{ Economic Growth Rate (R) } & \multicolumn{3}{|c|}{ GRDI per Capita (Y) } & \multirow[t]{2}{*}{ Conclusion } \\
\hline & Batu City (Rij) & East Java Province $(\mathbf{R} \mathbf{j})$ & Remark & Batu City (Yij) & East Java Province $(\mathbf{Y} \mathbf{j})$ & Remark & \\
\hline 2015 & $6.69 \%$ & $5.35 \%$ & $\mathrm{Rij}>\mathrm{Rj}$ & $57,412,660$ & $43,578,103$ & $\mathrm{Yij}>\mathrm{Yj}$ & Quadrant I \\
\hline 2016 & $6.61 \%$ & $5.80 \%$ & $\mathrm{Rij}>\mathrm{Rj}$ & $63,770,465$ & $47,473,717$ & $Y i j>Y j$ & Quadrant I \\
\hline 2017 & $6.56 \%$ & $5.08 \%$ & $\mathrm{Rij}>\mathrm{Rj}$ & $70,351,356$ & $51,388,318$ & $Y i j>Y j$ & Quadrant I \\
\hline 2018 & $6.71 \%$ & $4.94 \%$ & $\mathrm{Rij}>\mathrm{Rj}$ & $74,903,977$ & $55,436,368$ & $\mathrm{Yij}>\mathrm{Yj}$ & Quadrant I \\
\hline
\end{tabular}

Source: Data were processed 
Citation: Tuti Hastuti, et al., Strategies For Creative Economic Development In Malang Raya. Australian Journal of Basic and Applied Sciences, 13(10): 73-82. DOI: $10.22587 /$ ajbas.2019.13.10.10

Location Quotient Analysis has been carried out against the region studied. This research will only show result of the leading sector. Leading sectors in Malang City consist of: (a) Sector of Water Supply, Trash \& Waste Management, and Recycle; (b) Sector of Construction; (c) Sector of Wholesale \& Retail Tradings and Reparation of Cars \& Motorcycles; (d) Sector of Finance and Insurance Services; (e) Sector of Education Services; and (f) Sector of Health and Social Activity Services. Results of Static Location Quotient (SLQ) and Dynamic Location Quotient (DLQ) of Malang City are displayed in the following.

Table 4: SLQ and DLQ of Malang City from 2015 to 2018

\begin{tabular}{|c|c|c|c|c|c|c|}
\hline Category & Sector & $\begin{array}{c}\text { SLQ } \\
\text { Mean }\end{array}$ & Remark & $\begin{array}{c}\text { DLQ } \\
\text { Mean }\end{array}$ & Remark & Conclusion \\
\hline $\mathrm{A}$ & Agriculture, Forestry and Fishery & 0.0209 & $<1$ & 0.9961 & $<1$ & Laggard \\
\hline $\mathrm{B}$ & Mining and Excavation & 0.0164 & $<1$ & 0.9002 & $<1$ & Laggard \\
\hline $\mathrm{C}$ & Processing Industry & 0.8072 & $<1$ & 0.9729 & $<1$ & Laggard \\
\hline $\mathrm{D}$ & Electric and Gas Supplies & 0.1185 & $<1$ & 1.0336 & $>1$ & Dependable \\
\hline $\mathrm{E}$ & Water Supply, Trash \& Waste Management, and Recycle & 2.1350 & $>1$ & 1.0019 & $>1$ & Leading \\
\hline $\mathrm{F}$ & Construction & 1.3875 & $>1$ & 1.0094 & $>1$ & Leading \\
\hline G & $\begin{array}{c}\text { Wholesale \& Retail Tradings and Reparation of Cars \& } \\
\text { Motorcycles }\end{array}$ & 1.6958 & $>1$ & 1.0041 & $>1$ & Leading \\
\hline $\mathrm{H}$ & Transportation and Warehousing & 0.8700 & $<1$ & 1.0161 & $>1$ & Dependable \\
\hline $\mathrm{I}$ & Accommodation and Food \& Beverage Provisioning & 0.8659 & $<1$ & 1.0040 & $>1$ & Dependable \\
\hline $\mathrm{J}$ & Information and Communication & 0.8688 & $<1$ & 1.0163 & $>1$ & Dependable \\
\hline $\mathrm{K}$ & Finance and Insurance Services & 1.0284 & $>1$ & 1.0080 & $>1$ & Leading \\
\hline $\mathrm{L}$ & Real Estate & 0.8692 & $<1$ & 1.0133 & $>1$ & Dependable \\
\hline $\mathrm{M}, \mathrm{N}$ & Company Services & 0.9547 & $<1$ & 1.0133 & $>1$ & Dependable \\
\hline $\mathrm{O}$ & $\begin{array}{l}\text { Government Administration, Defense and Mandatory Social } \\
\text { Services }\end{array}$ & 0.6476 & $<1$ & 0.9908 & $<1$ & Laggard \\
\hline $\mathrm{P}$ & Education Services & 2.9498 & $>1$ & 1.0255 & $>1$ & Leading \\
\hline Q & Health and Social Activity Services & 3.9287 & $>1$ & 1.0241 & $>1$ & Leading \\
\hline $\mathrm{R}, \mathrm{S}, \mathrm{T}, \mathrm{U}$ & Other Services & 2.1584 & $>1$ & 0.9967 & $<1$ & Prospective \\
\hline
\end{tabular}

Leading sectors in Batu City comprise: (a) Sector of Agriculture, Forestry and Fishery; (b) Sector of Construction; (c) Sector of Wholesale \& Retail Tradings and Reparation of Cars \& Motorcycles; (d) Sector of Accommodation and Food \& Beverage Provisioning; and (e) Sector of Other Services. Results of SLQ and DLQ of Batu City are presented in the following.

Table 5: SLQ and DLQ of Batu City from 2015 to 2018

\begin{tabular}{|c|c|c|c|c|c|c|}
\hline Category & Sector & $\begin{array}{l}\text { SLQ } \\
\text { Mean }\end{array}$ & Remark & $\begin{array}{l}\text { DLQ } \\
\text { Mean }\end{array}$ & Remark & Conclusion \\
\hline A & Agriculture, Forestry and Fishery & 1.2627 & $>1$ & 0.0169 & $>1$ & Leading \\
\hline $\mathrm{B}$ & Mining and Excavation & 0.0329 & $<1$ & 0.9442 & $<1$ & Laggard \\
\hline $\mathrm{C}$ & Processing Industry & 0.1505 & $<1$ & 1.0021 & $>1$ & Dependable \\
\hline $\mathrm{D}$ & Electric and Gas Supplies & 0.1620 & $<1$ & 1.0471 & $>1$ & Dependable \\
\hline $\mathrm{E}$ & Water Supply, Trash \& Waste Management, and Recycle & 1.9774 & $>1$ & 0.9863 & $<1$ & Prospective \\
\hline $\mathrm{F}$ & Construction & 1.1846 & $>1$ & 1.0274 & $>1$ & Leading \\
\hline G & $\begin{array}{c}\text { Wholesale \& Retail Tradings and Reparation of Cars \& } \\
\text { Motorcycles }\end{array}$ & 1.0553 & $>1$ & 1.0041 & $>1$ & Leading \\
\hline $\mathrm{H}$ & Transportation and Warehousing & 0.4658 & $<1$ & 1.0033 & $>1$ & Dependable \\
\hline $\mathrm{I}$ & Accommodation and Food \& Beverage Provisioning & 2.0063 & $>1$ & 1.0038 & $>1$ & Leading \\
\hline $\mathbf{J}$ & Information and Communication & 1.3432 & $>1$ & 0.9876 & $<1$ & Prospective \\
\hline $\mathrm{K}$ & Finance and Insurance Services & 1.4253 & $>1$ & 0.9923 & $<1$ & Prospective \\
\hline $\mathrm{L}$ & Real Estate & 1.7091 & $>1$ & 0.9998 & $<1$ & Prospective \\
\hline $\mathrm{M}, \mathrm{N}$ & Company Services & 0.6236 & $<1$ & 0.9870 & $<1$ & Laggard \\
\hline $\mathrm{O}$ & $\begin{array}{l}\text { Government Administration, Defense and Mandatory Social } \\
\text { Services }\end{array}$ & 1.1118 & $>1$ & 0.9878 & $<1$ & Prospective \\
\hline $\mathrm{P}$ & Education Services & 1.4623 & $>1$ & 0.9928 & $<1$ & Prospective \\
\hline $\mathrm{Q}$ & Health and Social Activity Services & 1.2314 & $>1$ & 0.9750 & $<1$ & Prospective \\
\hline $\mathrm{R}, \mathrm{S}, \mathrm{T}, \mathrm{U}$ & Other Services & 11.8636 & $>1$ & 1.0147 & $>1$ & Leading \\
\hline
\end{tabular}

Leading sectors in Malang Regency include: (a) Sector of Agriculture, Forestry and Fishery; (b) Sector of Processing Industry; and (c) Sector of Other Services. Results of SLQ and DLQ of Malang Regency are shown in the following table. 
Citation: Tuti Hastuti, et al., Strategies For Creative Economic Development In Malang Raya. Australian Journal of Basic and Applied Sciences, 13(10): 73-82. DOI: $10.22587 /$ ajbas.2019.13.10.10

Table 6: SLQ and DLQ of Malang Regency from 2015 to 2018

\begin{tabular}{|c|c|c|c|c|c|c|}
\hline Category & Sector & $\begin{array}{c}\text { SLQ } \\
\text { Mean }\end{array}$ & Remark & $\begin{array}{l}\text { DLQ } \\
\text { Mean }\end{array}$ & Remark & Conclusion \\
\hline $\mathrm{A}$ & Agriculture, Forestry and Fishery & 1.4493 & $>1$ & 1.0136 & $>1$ & Leading \\
\hline $\mathrm{B}$ & Mining and Excavation & 0.3879 & $<1$ & 0.9543 & $<1$ & Laggard \\
\hline $\mathrm{C}$ & Processing Industry & 1.0193 & $>1$ & 1.0005 & $>1$ & Leading \\
\hline $\mathrm{D}$ & Electric and Gas Supplies & 0.3098 & $<1$ & 1.0564 & $>1$ & Dependable \\
\hline $\mathrm{E}$ & Water Supply, Trash \& Waste Management, and Recycle & 1.0065 & $>1$ & 1.9815 & $<1$ & Prospective \\
\hline $\mathrm{F}$ & Construction & 1.3048 & $>1$ & 1.9951 & $<1$ & Prospective \\
\hline G & $\begin{array}{l}\text { Wholesale \& Retail Tradings and Reparation of Cars \& } \\
\text { Motorcycles }\end{array}$ & 1.0532 & $>1$ & 0.9981 & $<1$ & Prospective \\
\hline $\mathrm{H}$ & Transportation and Warehousing & 0.3831 & $<1$ & 1.0094 & $>1$ & Dependable \\
\hline $\mathrm{I}$ & Accommodation and Food \& Beverage Provisioning & 0.6330 & $<1$ & 0.9933 & $<1$ & Laggard \\
\hline $\mathrm{J}$ & Information and Communication & 0.8785 & $<1$ & 0.9988 & $<1$ & Laggard \\
\hline $\mathrm{K}$ & Finance and Insurance Services & 0.6254 & $<1$ & 0.9945 & $<1$ & Laggard \\
\hline $\mathrm{L}$ & Real Estate & 0.8426 & $<1$ & 1.0054 & $>1$ & Dependable \\
\hline $\mathrm{M}, \mathrm{N}$ & Company Services & 0.4823 & $<1$ & 1.0054 & $>1$ & Dependable \\
\hline $\mathrm{O}$ & $\begin{array}{l}\text { Government Administration, Defense and Mandatory Social } \\
\text { Services }\end{array}$ & 0.8127 & $<1$ & 0.9933 & $<1$ & Laggard \\
\hline $\mathrm{P}$ & Education Services & 0.9211 & $<1$ & 1.0021 & $>1$ & Dependable \\
\hline Q & Health and Social Activity Services & 0.8926 & $<1$ & 0.9857 & $<1$ & Laggard \\
\hline $\mathrm{R}, \mathrm{S}, \mathrm{T}, \mathrm{U}$ & Other Services & 1.4282 & $>1$ & 1.0019 & $>1$ & Leading \\
\hline
\end{tabular}

\section{Shift Share (SS) Analysis}

Shift Share Analysis was executed against each region studied. Result of this analysis will be elaborated below.

\section{Malang City}

Net shift aggregate has a positive value and contributes by 304.2 (billions) Indonesian Rupiahs to Gross Regional Domestic Income from 2015 to 2018. Based on this result, Malang City is included within progressive (developed) category.

Table 7: Result of Net Shift Calculation for Malang City from 2015 to 2018

\begin{tabular}{|c|c|c|c|}
\hline \multirow{2}{*}{ Category } & \multirow{2}{*}{ Sector } & \multicolumn{2}{c|}{ Net Shift (NS) } \\
\cline { 3 - 4 } & & IDR Billion & Percentage \\
\hline A & Agriculture, Forestry and Fishery & -21.8 & -20.79 \\
\hline B & Mining and Excavation & -14.3 & -36.00 \\
\hline C & Processing Industry & $-1,257.6$ & -12.56 \\
\hline D & Electric and Gas Supplies & -1.9 & -12.00 \\
\hline E & Water Supply, Trash \& Waste Management, and Recycle & -1.1 & -1.31 \\
\hline F & Construction & 212.9 & 4.26 \\
\hline G & Wholesale \& Retail Tradings and Reparation of Cars \& Motorcycles & 385.8 & 3.16 \\
\hline H & Transportation and Warehousing & 111.8 & 11.43 \\
\hline I & Accommodation and Food \& Beverage Provisioning & 219.0 & 12.79 \\
\hline J & Information and Communication & 263.7 & 14.31 \\
\hline K & Finance and Insurance Services & 20.6 & 1.98 \\
\hline L & Real Estate & 20.2 & 3.45 \\
\hline M,N & Company Services & 20.2 & 7.08 \\
\hline O & Government Administration, Defense and Mandatory Social Services & -71.1 & -11.79 \\
\hline P & Education Services & 347.8 & 11.76 \\
\hline Q & Health and Social Activity Services & 147.4 & 15.23 \\
\hline R,S,T,U & Other Services & -77.3 & -6.07 \\
\hline & Total & $\mathbf{3 0 4 . 2}$ & $\mathbf{0 . 7 7}$ \\
\hline
\end{tabular}

Industrial Mix Share (IMS) and Local Share (LS) are the components in shift share analysis. Both are used as guides to categorize which sector is going to one of four quadrants. 


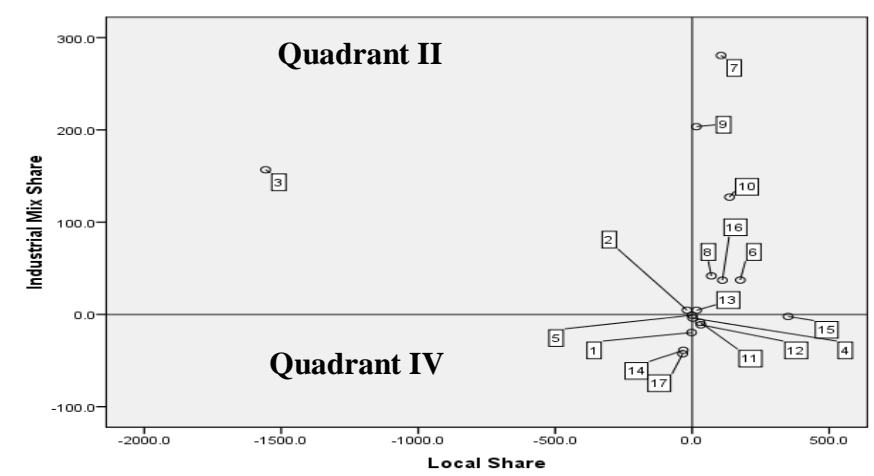

\section{Quadrant I}

Quadrant III

Figure 1. Quadrant Analysis of Economic Sectors in Malang City

Quadrant I (IMS=positive; LS=positive) is identified with fast growth rate and high competing ability. Sectors in Malang City that enter into this quadrant are Construction; Wholesale \& Retail Tradings and Reparation of Cars \& Motorcycles; Transportation and Warehousing; Accommodation and Food \& Beverage Provisioning; Information and Communication; Company Services; and Health and Social Activity Services. Quadrant II (IMS=negative; LS=positive) is indicated by fast growth rate but with poor competing ability. Sectors that occupy this quadrant are Mining and Excavation; and Processing Industry. Quadrant III (IMS=positive; $\mathrm{LS}=$ negative) is characterized by slow growth rate but with high competing ability. Sectors in this quadrant are in depression but still have potentials to be more developed in the future. These sectors are Electric and Gas Supplies; Finance and Insurance Services; Real Estate; and Education Services. Quadrant IV (IMS=negative; LS=negative) is recognized through laggardness (or depression) and poor competing ability. Sectors in this quadrant include Agriculture, Forestry and Fishery; Water Supply, Trash \& Waste Management, and Recycle; Government Administration, Defense and Mandatory Social Services; and Other Services.

\section{Malang Regency}

Malang Regency is put into the slow category because it gives negative contribution to Gross Regional Domestic Income, precisely as much as (-)246.6 (billions) Indonesian Rupiahs.

Table 8: Result of Net Shift Calculation for Malang Regency from 2015 to 2018

\begin{tabular}{|c|c|c|c|}
\hline \multirow{2}{*}{ Category } & Sector & \multicolumn{2}{c|}{ Net Shift (NS) } \\
\cline { 2 - 4 } & IDR Billion & Percentage \\
\hline A & Agriculture, Forestry and Fishery & $-1,138.8$ & -12.35 \\
\hline B & Mining and Excavation & -116.3 & -10.60 \\
\hline C & Processing Industry & 456.7 & 2.94 \\
\hline D & Electric and Gas Supplies & 0.2 & 0.40 \\
\hline E & Water Supply, Trash \& Waste Management, and Recycle & -4.8 & -9.01 \\
\hline F & Construction & -33.7 & -0.53 \\
\hline G & Wholesale \& Retail Tradings and Reparation of Cars \& Motorcycles & 254.5 & 2.53 \\
\hline H & Transportation and Warehousing & 58.9 & 10.40 \\
\hline I & Accommodation and Food \& Beverage Provisioning & 159.3 & 9.53 \\
\hline J & Information and Communication & 189.4 & 7.52 \\
\hline K & Finance and Insurance Services & -19.9 & -2.34 \\
\hline L & Real Estate & 14.3 & 1.89 \\
\hline M,N & Company Services & 10.4 & 5.46 \\
\hline O & Government Administration, Defense and Mandatory Social Services & -82.7 & -8.46 \\
\hline P & Education Services & 27.2 & 2.16 \\
\hline Q & Health and Social Activity Services & -6.9 & -2.22 \\
\hline R,S,T,U & Other Services & -14.3 & -1.32 \\
\hline & Total & $\mathbf{- 2 4 6 . 6}$ & $\mathbf{- 0 . 4 7}$ \\
\hline
\end{tabular}

Both Industrial Mix Share (IMS) and Local Share (LS) are used to determine which sector that enters to one of four quadrants. 


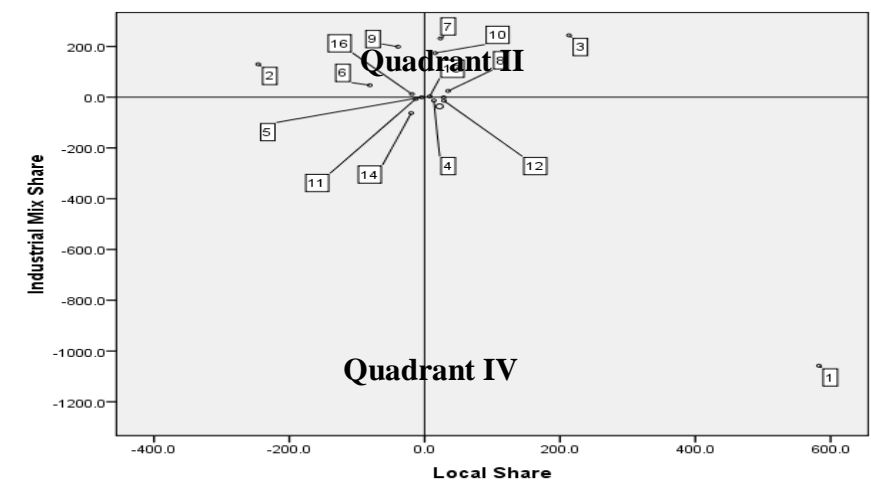

\section{Quadrant I}

Quadrant III

Figure 2. Quadrant Analysis of Economic Sectors in Malang Regency

Sectors in Quadrant I (IMS=positive; LS=positive) are indicated by their fast growth rate and high competing ability. Those sectors are Processing Industry; Wholesale \& Retail Tradings and Reparation of Cars \& Motorcycles; Transportation and Warehousing; Information and Communication; and Company Service. Sectors in Quadrant II (IMS=negative; LS=positive) are actually depressed but still have the capability to develop (developing). Their growth rate is fast but lacking competing ability. Those sectors include: Mining and Excavation; Construction; Accommodation and Food \& Beverage Provisioning; and Health and Social Activity Services. Sectors that occupy Quadrant III (IMS=positive; LS=negative) are mostly depressed but still have potentials to be more developing. Their competing ability is fine but growth rate is slow. The occupant sectors include Agriculture, Forestry and Fishery; Electric and Gas Supplies; Real Estate; Education Services; and Other Services. In Quadrant IV (IMS=negative; LS=negative), the occupant sectors are recognized through their laggardness (or depression) and without competing ability. Sectors in this quadrant comprise Water Supply, Trash \& Waste Management, and Recycle; Finance and Insurance Services; and Government Administration, Defense and Mandatory Social Services.

\section{Batu City}

Batu City is a progressive (developed) region. Its contribution to Gross Regional Domestic Income is positive as much as 471.9 (billions) Indonesian Rupiahs.

Table 9: Result of Net Shift Calculation for Batu City from 2015 to 2018

\begin{tabular}{|c|c|c|c|}
\hline \multirow{2}{*}{ Category } & \multirow{2}{*}{ Sector } & \multicolumn{2}{c|}{ Net Shift (NS) } \\
\cline { 2 - 5 } A & Agriculture, Forestry and Fishery Billion & Percentage \\
\hline B & Mining and Excavation & -122.7 & -9.25 \\
\hline C & Processing Industry & -2.1 & -13.18 \\
\hline D & Electric and Gas Supplies & 23.8 & 6.25 \\
\hline E & Water Supply, Trash \& Waste Management, and Recycle & -0.1 & -1.47 \\
\hline F & Construction & -0.7 & -4.30 \\
\hline G & Wholesale \& Retail Tradings and Reparation of Cars \& Motorcycles & 167.1 & 18.91 \\
\hline H & Transportation and Warehousing & 133.0 & 8.08 \\
\hline I & Accommodation and Food \& Beverage Provisioning & 11.2 & 9.73 \\
\hline J & Information and Communication & 153.4 & 17.95 \\
\hline K & Finance and Insurance Services & 26.5 & 4.09 \\
\hline L & Real Estate & -3.7 & -1.15 \\
\hline M,N & Company Services & 3.7 & 1.43 \\
\hline O & Government Administration, Defense and Mandatory Social Services & -0.6 & -1.43 \\
\hline P & Education Services & -20.1 & -8.90 \\
\hline Q & Health and Social Activity Services & -0.6 & -0.17 \\
\hline R,S,T,U & Other Services & -3.8 & -5.20 \\
\hline & Total & 107.5 & 7.58 \\
\hline
\end{tabular}


Citation: Tuti Hastuti, et al., Strategies For Creative Economic Development In Malang Raya. Australian Journal of Basic and Applied Sciences, 13(10): 73-82. DOI: 10.22587/ajbas.2019.13.10.10

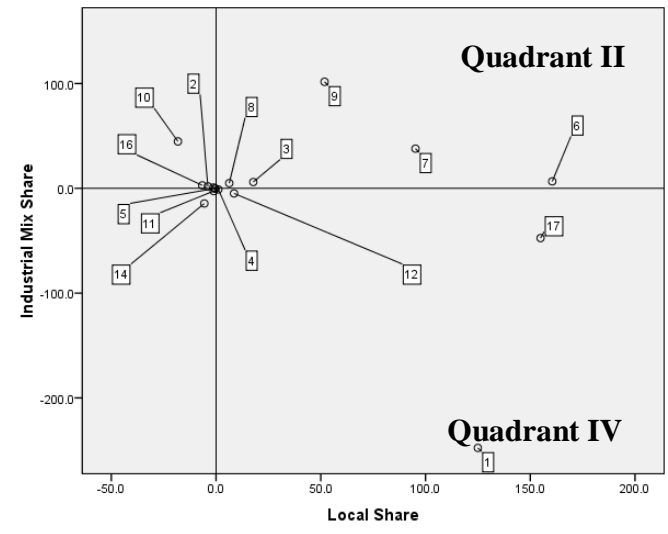

Quadrant I

\section{Quadrant III}

Figure 3. Quadrant Analysis of Economic Sectors in Batu City

Within Batu City context, sectors in Quadrant I (IMS=positive; LS=positive) are characterized by their fast growth rate and high competing ability. Those sectors include Processing Industry; Construction; Wholesale \& Retail Tradings and Reparation of Cars \& Motorcycles; Transportation and Warehousing; and Accommodation and Food \& Beverage Provisioning. Sectors in Quadrant II (IMS=negative; LS=positive) are depressed but still developing. Their growth rate may be fast but with poor competing ability. Those sectors are Mining and Excavation; Information and Communication; Company Services; and Health and Social Activity Services. Quadrant III (IMS=positive; LS=negative) comprise sectors that are depressed but still having potentials to be more developed. Their high competing ability is in contrast with their slow growth rate. The occupant sectors include Agriculture, Forestry and Fishery; Electric and Gas Supplies; Real Estate; and Other Services. Sectors that occupy Quadrant IV (IMS=negative; LS=negative) are identified with laggardness (or depression) and poor competing ability. Sectors in this quadrant are: Water Supply, Trash \& Waste Management, and Recycle; Finance and Insurance Services; Government Administration, Defense and Mandatory Social Services; Education Services; and Other Services.

\section{SWOT Analysis}

Factors that influence growth and development of creative economy in Malang Raya have been mapped in SWOT analysis. The result shows that create economic in Malang Raya is situated in strategic position of growth and development. Finally, the strategy alternative suggested to be applied in the future to develop creative economic is market development strategy.

\section{Targets, Directions, Strategies, and Programs of Creative Economic Development in Malang Raya}

All targets, directions, strategies and programs of creative economic development are always taking into account conditions, potentials and problems that may affect the success of the creative economy. Some development models are offered, and these are explained as follows.

1. Creative human resources must be increased in numbers and also made to be sustainable. It can be done by a strategy of facilitating access for information and knowledge sharing among individuals (physically or through information technology) either at local, national or international levels. Government offices can be involved into this activity, such as the Office of Communication and Information, the Office of National Education, Regional Development Planning Agency, the Office of Employment and Transmigration, the Office of Culture and Tourism, the Office of Trade, and the Office of Cooperative and Small \& Medium Enterprises.

2. The local government shall improve its commitment and political will for creative economic by giving creative human resources the recognitions that have economic and social added values. This can be done with strategy comprising elements as follows: facilitating the talented creative human resources who have interest to enter international market; giving support to activities and organizations related with art, culture and knowledge \& technology, to keep them contributing to creative industry; organizing events and programs to explore, recognize and promote creative talents in the community; and building partnership between successful and potential creative human resources, and then empowering those potentials through mentoring. Government offices that can be involved into this activity are the Office of Communication and Information, the Office of National Education, Regional Development Planning Agency, the Office of Employment and Transmigration, the Office of Culture and Tourism, the Office of Trade, and the Office of Cooperative and Small \& Medium Enterprises.

3. Creative entrepreneurs must be increased in numbers because it may help to grow creative jobs. This can be actualized through strategy as follows: giving creative entrepreneurs the access to business issues (capital, permit and marketing); and building a partnership among business actors and using this partnership as business coaching organization.

4. Creative industry must be made more attractive where people will pursue their career and make an investment within this industry. Strategy to make this coming true is as follows: enhancing distribution coverage, which can be done by expanding distribution channel; increasing market appreciation to products/services from creative industry; conducting and archiving researches concerning domestic and foreign markets for creative industry's products and services; promoting creative industry's products and services in domestic and foreign markets to keep consumers still knowing about them; and managing 
Citation: Tuti Hastuti, et al., Strategies For Creative Economic Development In Malang Raya. Australian Journal of Basic and Applied Sciences, 13(10): 73-82. DOI: $10.22587 / a j b a s .2019 .13 .10 .10$

and revitalizing regulations concerning distribution, import-export (protection, tariff, quota), and subsidy (pure art), to assure the obtaining of added-values and to improve market potentials.

5. Creative industry must be made more efficient and productive to increase competitive advantage. Strategy to materialize it is as follows: reorganizing subordinate industries that support the creative industry by redefining regulations concerning raw materials, cultivation, and relocation; conducting innovative research about alternative raw materials; and providing importexport incentives for creative industry's products and services.

6. Local content innovation shall be improved to create a competitive advantage. It can be brought into reality with strategy of revitalizing regulations concerning the imported technology that supports creative industry.

7. A business climate that encourages investment into technological infrastructures must be empowered. Strategy to realize this goal is as follows: evaluating policies relating with export of biological commodities that are used as main raw material of creative industry; and making trade rules concerning biological commodities for creative industry, which later shall be in favor of farmers and entrepreneurs in creative industry.

8. Copyright and other recognitions with economic value shall be given to creative individuals. This goal can be achieved through a strategy of optimizing business interaction base between creative enterprises and creative individuals, which among others is establishing business contract standards that respect copyright (royalty system, plagiarism prevention, etc).

9. Appreciation to local cultural arts can be empowered by giving recognitions to any local content products with cultural qualities. This can be attained by a strategy of conducting a campaign to use domestic creative products, especially those from Malang Raya, to keep community appreciative to their local culture.

10. The international world can be made aware of and recognize cultural products and services provided by Malang Raya creative industry. Strategy to reach this goal is by constructing concepts and strategies about Malang Raya, and making a campaign about cultural diversity, natural beauty, and international market taste to Malang Raya people.

\section{CONCLUSION}

In 2018, the economic development pattern of Malang City exists at Quadrant I. This City grows and develops fast. Economic growth rate and income per capita of this City are averagely higher than other regions in East Java. Meanwhile, Malang Regency resides at Quadrant IV because it is relatively laggard. Economic growth rate and income per capita of this Regency are averagely lower than other regions in East Java. Batu City is in Quadrant I because this City has fast growth and development. Economic growth rate and income per capita of Batu City are averagely higher than other regions in East Java. Leading sectors in Malang City comprise: (a) Sector of Water Supply, Trash \& Waste Management, and Recycle; (b) Sector of Construction; (c) Sector of Wholesale \& Retail Tradings and Reparation of Cars \& Motorcycles; (d) Sector of Finance and Insurance Services; (e) Sector of Education Services; and (f) Sector of Health and Social Activity Services. Leading sectors in Batu City are: (a) Sector of Agriculture, Forestry and Fishery; (b) Sector of Construction; (c) Sector of Wholesale \& Retail Tradings and Reparation of Cars \& Motorcycles; (d) Sector of Accommodation and Food \& Beverage Provisioning; and (e) Sector of Other Services. Leading sectors in Malang Regency include: (a) Sector of Agriculture, Forestry and Fishery; (b) Sector of Processing Industry; and (c) Sector of Other Services. Result of SWOT analysis demonstrated that strategic position of creative economic in Malang Raya is described as that growing and developing. Strategy alternative suggested to be used in the future is market development strategy.

\section{Acknowledgements}

The author extends big gratitude to DP2M DIKTI for the funding provided to this research for three years. Appreciation is also bestowed to other related parties including the local government of Malang Raya for its facilitation provided, creative economic entrepreneurs, LPPM of Malang Widyagama University, and also research team. The author also thanks to anyone who may not yet be mentioned here for their assistance in the completion of this research.

\section{REFERENCES}

Dias Satria and Ayu Prameswari. 2011. Problems in Creative Industry of Clothing Distribution Outlets in Malang City. JAM. Vol 9 No 1. Faculty of Economy, Malang Brawijaya University.

Gunarianto and M. Nasri. 2011. Review on Competence of Local Industries in Pasuruan City. Result of Research.

Gunarianto. 2018. The Use Of One Tambon One Product Model As The Strategy to Improve Competitive Advantage And Market Access of Micro, Small And Medium Enterprises In Effort to Attain Better Development In Welcoming ASEAN Market In Great Malang. Australian Journal of Basic And Applied Sciences. Vol. 12(9). September

Media Indonesia. 2019. Creative Industry in Era 4.0. E-paper.

Netty Purnamasari. 2014. Analysis on Contribution of Tourism Sector Creative Economic to Community Welfare Improvement in Batu City. Paper for Faculty of Economy, Malang Brawijaya University.

Siti Asiyah, Gunarianto and Tuti Hastuti. 2007. Formulation of Policy Concept for Improving Quality of Micro \& Small Industry Centers in Blitar City. Result of Research.

Siti Asiyah, Gunarianto and Alfiana. 2008. Review on Capital Investment into Sector of Trade and Service of Micro, Small and Medium Enterprises in Blitar City. Faculty of Economy, Malang Widyagama University. Result of Research. 
Tuti Hastuti, Alfiana and Siti Asiyah. 2013. Micro, Small and Medium Enterprises Empowerment Model as the Effort for Poverty Eradication in Malang Raya. Result of Competitive Bequest Research (PHB). DP2M-DIKTI.

Tuti Hastuti, Alfiana and Siti Asiyah. 2014. Micro, Small and Medium Enterprise (MSME) Empowerment Model as the Effort for Poverty Eradication in Malang Raya. International Journal of Business and Management Invention (IJBMI) Vol. 3 - Issues 1 (January-2014 Version).

Tuti Hastuti, Alfiana and Siti Asiyah. 2015. Micro, Small and Medium Enterprise (MSME) Empowerment Model as the Effort for Poverty Eradication in Malang Raya. International Journal of Business and Management Invention (IJBMI) Volume 4Issues 1-Version 1 (January-2015 Version). Result of Competitive Bequest Research on Second Year.

Tuti Hastuti, Marjani AT and Endah PS. 2018. Strategies for Developing the Creative Economy in Great Malang as an Effort to Improve Competitive Advantage of Local Economic Enterprises. Australian Journal of Basic And Applied Sciences. Vol. 12(11). November. DOI: 10.22587/ajbas.2018.12.11.10

Wahyuni, E, et.al. 2005. Problems That Challege Micro, Small and Medium Enterprises, and Policy Controversy (Case Study at North Sumatera). Medan: Bitra Indonesia Publishing.

Yudha Prasetyawan, Alia D., Heru Sucahyo and M. Ziyad. 2013. Identification of Lamp-Hood Making as Core Competence and Leading Product of Creative Industry in Malang Regency. National Symposium of RAPI VIII. Surakarta 